\title{
Iron enriched Saccharomyces cerevisiae maintains its fermenting power and bakery properties
}

\author{
Saccharomyces cerevisiae enriquecida com ferro mantém sua capacidade fermentativa \\ e características de panificação
}

\author{
Fernanda GAENSLY ${ }^{1}$, Grace Maria Ferreira de Castro WILLE ${ }^{1}$, Debora BRAND ${ }^{1}$, Tania Maria Bordin BONFIM ${ }^{1 \star}$
}

\begin{abstract}
Iron is an essential micronutrient in the metabolism of almost all living organisms; however, its deficiency is well documented especially in pregnant women and in children. Iron salts as a dietary supplement have low bioavailability and can cause gastrointestinal discomforts. Iron enriched yeasts can provide a supplementation of this micronutrient to the diet because this mineral has a better bioavailability when bonded to yeast cell macromolecules. These yeasts can be used as feed supplement for human and animals and also as baker's yeast. Baker's yeast Saccharomyces cerevisiae was cultivated in a reactor employing yeast media supplemented with $497 \mathrm{mg}$ ferrous sulfate. $\mathrm{L}^{-1}$, and the resultant biomass incorporated $8 \mathrm{mg} \mathrm{Fe} . \mathrm{g}^{-1}$ dry matter. This biomass maintained its fermenting power regarding both water displace measurement through carbonic dioxide production and bakery characteristics. The bread produced using the yeast obtained by cultivation in yeast media supplemented with iron presented six times more iron than the bread produced using the yeast obtained by cultivation without iron supplementation.
\end{abstract}

Keywords: Saccharomyces cerevisiae; baker's yeast; iron supplementation; fermenting power; bakery.

\section{Resumo}

O ferro é um micronutriente essencial para o metabolismo dos organismos; entretanto, sua deficiência é observada principalmente em gestantes e em crianças. Sais de ferro suplementados à dieta possuem baixa biodisponibilidade e podem causar desconfortos gastrointestinais. Leveduras enriquecidas com ferro podem ser um veículo para a suplementação deste mineral à dieta, pois a ligação do ferro com macromoléculas presentes nas células da levedura torna este mineral mais biodisponível. O cultivo da levedura de panificação Saccharomyces cerevisiae em reator, empregando meio YM (Yeast Media) suplementado com $497 \mathrm{mg}$ de sulfato ferroso.L $\mathrm{L}^{-1}$, resultou em biomassa com cerca de 8 mg Fe.g ${ }^{-1}$ de célula seca. A biomassa obtida manteve sua capacidade fermentativa tanto no que se refere ao deslocamento de água pela produção de gás carbônico como pelas suas características de panificação. O pão produzido com a levedura obtida por cultivo em meio YM suplementado com ferro obteve seis vezes mais ferro que o pão produzido com a levedura cultivada em meio sem suplementação.

Palavras-chave: Saccharomyces cerevisiae; levedura de panificação; suplementação de ferro; capacidade fermentativa; panificação.

\section{Introduction}

Food enrichment or food fortification is a widely known technique employed by industries, which aims at reinforcing the nutritive value or correct deficiencies of one or more nutrient element. Bread is one of the most popular foods and daily calorie sources in the world; therefore, there are several studies regarding its enrichment with minerals.

Iron has several vital functions in the body. It acts as an oxygen carrier to the tissues, as a carrier for electrons within cells, and as an integrated part of important enzyme systems. Most of the iron in the body is in the erythrocytes, as a hemoglobin component. Iron is reversibly stored within the liver as ferritin and hemosiderin, whereas it is transported between different compartments in the body by the protein transferrin (WORLD..., 2004).

Regarding daily minerals ingestion, Brazilian resolution RDC $n^{\circ} 269$ from September $22^{\text {th }}, 2005$ determines that an adult should ingest $14 \mathrm{mg}$ of iron daily. This resolution also determines the daily iron intake for other groups: children up to 6 months require $0.27 \mathrm{mg}$ daily and up to 11 months this requirement rise up to $9 \mathrm{mg}$ of iron. Children up to 6 years should ingest $6 \mathrm{mg}$ of iron daily and up to 10 years, $9 \mathrm{mg}$. The recommended daily intake of iron for pregnant and lactating women is 27 and $15 \mathrm{mg}$, respectively. These values consider that the iron bioavailability in food is around $10 \%$. World Health Organization (WHO) estimates that $39 \%$ of children younger than 5 years, $48 \%$ of children between 5 and 14 years, $42 \%$ of all women, and $52 \%$ of pregnant women in developing countries are anemic, and half have iron deficiency anemia (ZIMMERMANN; HURRELL, 2007).

In Brazil, aiming at preventing iron deficiency anemia and neural tube pathologies, Resolution $\mathrm{RDC} \mathrm{n}^{\circ} 34$, from December $13^{\text {th }}, 2002$, determines that all whey and corn flour

Received 21/6/2010

Accepted 3/11/2010 (004892)

1 Universidade Federal do Paraná, Av. Lothário Meissner, 632, Jd Botânico, CEP 80210-170, Curitiba, PR, Brasil, e-mail: fernanda.gaensly@gmail.com; dbrand@ufpr.br; tbonfim@ufpr.br; gwille@subsede.ufpr.br

${ }^{*}$ Corresponding author 
should be supplemented with iron and folic acid. Regarding iron supplementation, it is mandatory that each $100 \mathrm{~g}$ of corn or whey flour provide a minimum of $4.2 \mathrm{mg} \mathrm{Fe}$. This legislation also reinforces that the companies should assure that the chosen iron compound is food grade and has an attested bioavailability.

There are different types of bread worldwide although its basic ingredients are usually cereal flour, water, yeast or another leavening agent, and salt. During bread making, the availability and levels of bioactive compounds in cereal grains can either decrease or increase (DEWETTINCK et al., 2008).

Cereals are often a primary provider of nutritious protein and also a major source of energy and fibers in diet. Cereals contain about 1.5 to $2.5 \%$ of minerals. Phosphorus is the mineral in highest concentration (16 to $22 \%$ of the total ash content), and it is generally associated with calcium phytate and magnesium phytate. Wheat, rye, barley, and oats are also classified as moderate sources of calcium, magnesium (100 to $200 \mathrm{mg} .100 \mathrm{~g}^{-1}$ ), iron, zinc ( 1 to $\left.5 \mathrm{mg} .100 \mathrm{~g}^{-1}\right)$, and copper ( 0.1 to $\left.1 \mathrm{mg} .100 \mathrm{~g}^{-1}\right)$. In addition, a large number of other elements are present in trace quantities. Cereals are an important source of minerals, but they also contain phytic acid, which is considered and anti-nutritional factor. Phytic acid has a high chelating activity, which may decrease the bioavailability of some minerals (DEWETTINCK et al., 2008).

Some studies show that diets rich in fibers and in whole grains can result in lower heme and non-heme iron bioavailability due to the increased ingestion of phytic acid (KRISTENSEN et al., 2005).

On the other hand, it has been shown that organically bonded microelements have superior bioavailability, a good resorption from human digestive tract, and are less toxic than their inorganic compounds. One of the methods of producing microelements bonded to organic substracts is by growing yeast cells in a medium supplemented with micronutrients. Under certain physicochemical conditions, yeasts are able to bond to different minerals and incorporate them at concentrations higher than the physiological concentrations (SUHAJDA et al., 2000; MRVCIC et al., 2007).

The yeast Saccharomyces cerevisiae is usually employed as a source of enzymes, unicellular protein, and vitamins; it is also employed as a flavoring and fermenting agent. Moreover, it is commonly used in fermentation processes, in beer manufacturing, and in bakery. The fermentation activity of baker's yeast is an important factor to be considered during bread manufacturing. The yeast should have a good biomass formation in aerobic conditions and should also be capable to quickly adapt to anaerobic conditions during bread dough fermentation (BASAPPA, 1999).

The yeast market is in constant search for new products and processes and can incorporate biotechnological advances. The nutraceutical segment in this market is the one that presents a constant growth in food industry. Bread, as a daily consumed food product, is likely to become a functional nutriment (WINDE, 2003).
The use of the baker's yeast Saccharomyces cerevisiae which keeps its fermenting properties when grown in media supplemented with inorganic iron can be an option to provide iron supplementation to human diet in bakery products. Iron enriched yeast biomass, when used in bakery, could also be a safer choice to anemia prevention.

The objectives of this study are: cultivate baker's yeast Saccharomyces cerevisiae in culture media containing $100 \mathrm{mg} \mathrm{Fe} . \mathrm{L}^{-1}$ employing ferrous sulfate as iron source and in media without iron supplementation; analyze the fermentation power of the harvested yeast cells and their capacity to ferment dough; and determine the iron content in the breads.

\section{Material and methods}

\subsection{Analysis}

The results were obtained from two independent duplicated experiments and all analytical determinations were performed in triplicates. The results are presented as the mean obtained \pm standard deviation.

\subsection{Microorganism}

The yeast Saccharomyces cerevisiae was isolated from fresh compressed baker's yeast ferment. After isolation, the yeast strain was maintained in yeast media agar slants $\left(10\right.$ g.L $\mathrm{L}^{-1}$ dextrose; 5 g.L. $\mathrm{L}^{-1}$ peptone; 3 g. $\mathrm{L}^{-1}$ yeast extract, 3 g.L. $\mathrm{L}^{-1}$ malt extract, and 20 g. $\mathrm{L}^{-1}$ agar) at $4{ }^{\circ} \mathrm{C}$ and transferred every 2 months.

\subsection{Inoculum preparation}

A suspension of the yeast culture grown in yeast media agar slants at $28^{\circ} \mathrm{C}, 24$ hours was used as the pre-inoculum. The inoculum was obtained from a suspension of cells harvested from the pre-inoculum. The inoculum was grown in Erlenmeyer flasks containing yeast media ( 10 g.L. $\mathrm{L}^{-1}$ dextrose; 5 g. $\mathrm{L}^{-1}$ peptone; 3 g.L. $\mathrm{L}^{-1}$ yeast extract, and $3 \mathrm{~g} . \mathrm{L}^{-1}$ malt extract) in a volume that respected the ratio 1:5 regarding media volume to flask volume; the flasks were incubated in a rotary shaker at $150 \mathrm{rpm}, 28^{\circ} \mathrm{C}$, 12 hours.

\subsection{Bioreactor cultivation}

Yeast media (10 g.L $\mathrm{L}^{-1}$ dextrose; 5 g.L. $\mathrm{L}^{-1}$ peptone; 3 g.L. $\mathrm{L}^{-1}$ yeast extract; 3 g.L $\mathrm{L}^{-1}$ malt extract) was employed for biomass cultivation with and without iron supplementation. The medium supplemented with iron was added with $497 \mathrm{mg}$ ferrous sulfate. $\mathrm{L}^{-1}$ (corresponding to $100 \mathrm{mg} \mathrm{Fe} . \mathrm{L}^{-1}$ ). The initial $\mathrm{pH}$ for both media was adjusted to 4.5 using a 1 mol. $\mathrm{L}^{-1}$ sulfuric acid solution.

The cultivations were performed in two $5 \mathrm{~L}$-glass bioreactors (New Brunswick Scientific Co, Drive Assembly) using 60\% of the total bioreactor volume capacity under controlled conditions of temperature, stirring, and aeration $\left(30{ }^{\circ} \mathrm{C}, 100 \mathrm{rpm}\right.$ and $2 \mathrm{vvm}$ ). The $\mathrm{pH}$ at the beginning of the process was 4.5 , and no $\mathrm{pH}$ correction was necessary. The cultivations started by adding the inoculum $(10 \% \mathrm{v} / \mathrm{v})$ to the culture media. Both processes 
started with a viable cell concentration of $1.10^{7}$ cells. $\mathrm{mL}^{-1}$. After 12 hours, the cells were harvested and separated from the medium by $4000 \mathrm{rpm}$ centrifugation for 5 minutes. The harvested cells were washed with saline solution for complete medium removal. The dry cellular concentration, intracellular iron content, moisture content, and fermentation power were determined.

\subsection{Analytical methods}

The $\mathrm{pH}$ was determined using a WTW 303i pH meter.

The dry cell weight was determined by drying the yeast biomass to a constant weigh at $60^{\circ} \mathrm{C}$ after centrifuging $10 \mathrm{~mL}$ of the samples at $6000 \mathrm{rpm}$ and washing the cell pellet for complete medium removal. The same procedure was used to moisture content determination.

\subsection{Iron quantification}

The iron incorporated into yeast cells and residual iron in cultivation media were determined by colorimetric methodology. The yeast cells were digested using $\mathrm{HNO}_{3} 3 \%, 24$ hours, $98^{\circ} \mathrm{C}$ to release the intracellular iron. The nitric acid containing the digested cells or the cultivation media was mixed with sodium ascorbate, ammonium acetate, and BPS, an iron chelating agent. The iron-BPS complex absorbance was recorded at $535 \mathrm{~nm}$ in a Shimadzu UV 1601 - PC spectrophotometer. This determination accompanies a calibration curve (TAMARIT et al., 2006).

The iron content in the breads was analyzed using a Varian Spectra AA 100-200 atomic absorption spectrophotometer. A normal calibration curve was used.

\subsection{Fermentation power}

The fermentation power of yeast can be measured by its ability to ferment glucose or maltose by the detection of gas production (STABNIKOVA et al., 2008). The fermentation power of the harvested yeast cells was evaluated through the measurement of the carbon dioxide production during the fermentation of $10 \%$ glucose solution at $30{ }^{\circ} \mathrm{C}$. The $\mathrm{CO}_{2}$ production displaced an equal volume of water, which was measured for 120 minutes with intervals of 30 minutes (WALTER, 1953). The fermentation power results are presented in $\mathrm{ml}$ of displaced water/minute.

\subsection{Preparation of bread and yeast bakery characteristics}

The dietary breads were prepared using the yeast biomass harvested from bioreactor cultivations with and without iron supplementation, following the recipe: commercial wheat flour, $100 \mathrm{~g}$; water, $40 \mathrm{~g}$; hydrogenated vegetal fat, $5.0 \mathrm{~g}$; sugar, $2.0 \mathrm{~g}$; salt, $1.0 \mathrm{~g}$. The number of yeast cells from each cultivation was determined in order to use an amount of $4.10^{10}$ yeast cells in each bread. The dough was hand kneaded and left to rest in order to double its initial volume. Next, the dough was kneaded, shaped, placed in adequate pans, and left to rest until it doubled its volume again. The dough's rising power was evaluated considering the time needed for the dough ball to rise from the bottom of the container full of water. The breads were baked in an oven at a temperature of $180 \pm 5^{\circ} \mathrm{C}$ for 45 minutes.

\section{Results and discussion}

Baker yeast Saccharomyces cerevisiae cultivations in bioreactor employing yeast media with and without ferrous sulfate addition presented different values of biomass formation and indicate that the quantity of iron added to de medium did not inhibit biomass formation. Cellular concentrations obtained in the cultivations carried out with and without iron supplementation were $0.217 \pm 0.002 \mathrm{~g} \%$, and $0.265 \pm 0.002 \mathrm{~g} \%$, respectively.

When the yeast was cultivated employing the media supplemented with iron, the intracellular iron content was $8.062 \pm 0.251 \mathrm{mg} \mathrm{Fe} . \mathrm{g}^{-1}$ dry matter at the end of the cultivation period. The residual iron that remained in the cultivation media was $78.155 \pm 4.313 \mathrm{mg} \mathrm{Fe} . \mathrm{L}^{-1}$. The intracellular iron content and residual iron evaluations were also performed for the cultivation without iron supplementation with any significant iron content results. The moisture content of the yeast cells of both cultivations was $78 \%$.

Considering glucose activity fermenting power, the obtained yeast cells with and without increased intracellular iron, displaced a similar water volume at 30,60 and 90 minutes.

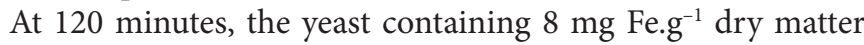
displaced $430 \mathrm{~mL}$ of water, and the yeast without increase iron content displaced $395 \mathrm{~mL}$ (Figure 1).

When iron is abundant in the environment, vacuoles accumulate it, and this sequestration protects cells from the toxic effect of iron and allows cells to utilize it when extracellular iron is scarce (PHILPOTT; PROTCHENKO, 2008). It could be suggested that the yeast containing intracellular iron, after 120 minutes of fermentation, might have mobilized the iron to use it in respiratory activities, explaining the increase in the volume of displaced water. It is known that Saccharomyces cerevisiae requires certain quantity of iron that plays and important role in the reactions of citric acid cycle and in many parts of the respiratory chain (STEHLIKTHOMAS et al., 2003; PAS et al., 2007). It is also documented that the yeast Saccharomyces cerevisiae exhibits strategies to respond to iron availability fluctuations in its environment, including the mobilization of its intracellular stores (PHILPOTT; PROTCHENKO, 2008).

Bakery properties of the yeasts grown in media containing ferrous sulfate did not differ much from those of yeast cultivated in the medium without iron supplementation.

After the dough preparation, the rising power test was performed. The dough ball prepared using yeast without iron supplementation took 2 minutes to float up, and the dough ball prepared using the yeast supplemented with iron took 3 minutes. The ability of the yeast enriched with iron to ferment the bread dough was similar to the yeast grown in media without supplementation. The time required during the two intervals until the dough doubled its volume was 15 minutes. Both breads presented air bubbles dispersed homogeneously after baking. 


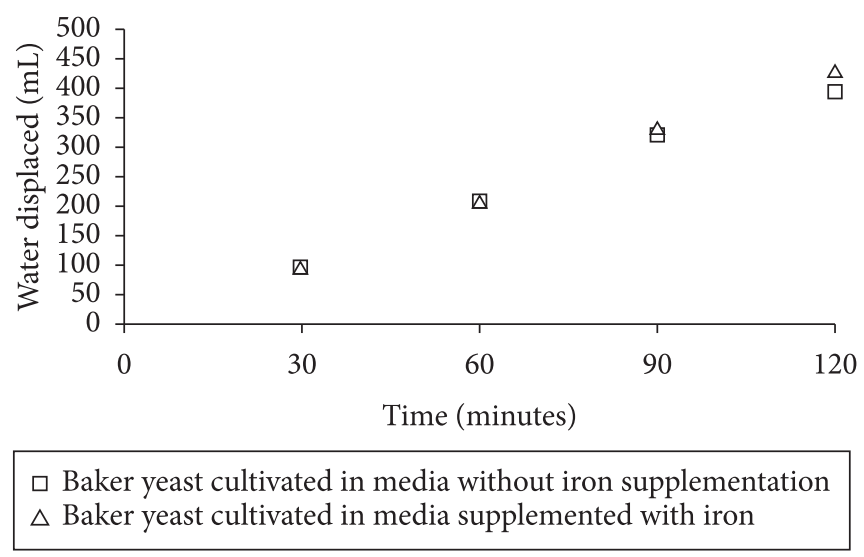

Figure 1. Volume of water displaced $(\mathrm{mL})$ due to carbon dioxide production by the baker yeast Saccharomyces cerevisiae cultivated in media with and without iron supplementation (ferrous sulphate 497 mg. $\left.\mathrm{L}^{-1}\right)$.

The breads obtained were analyzed regarding iron content. The bread produced using the yeast cells cultivated in the media without iron supplementation presented $4.17 \mathrm{mg} \mathrm{Fe} .100 \mathrm{~g}^{-1}$ of bread, and most of this iron content is likely to be resultant from the commercial flour. The bread produced using the yeast cells cultivated in the media supplemented with iron exhibited $24.164 \mathrm{mg} \mathrm{Fe} 100 \mathrm{~g}^{-1}$ of bread.

\section{Conclusion}

The fermentation power and the bakery characteristic results indicate that the yeast biomass cultivated in media with iron addition keeps its fermenting power and could be employed as an iron source for supplementing bakery products.

The bread produced using the baker yeast Saccharomyces cerevisiae, obtained by cultivation in media supplemented with $100 \mathrm{mg} \mathrm{Fe} . \mathrm{L}^{-1}$, showed an iron content of $24.164 \mathrm{mg}$ Fe. $100 \mathrm{~g}^{-1}$ of bread, six times higher than that of the bread produced using the yeast cells obtained by cultivation in media without iron supplementation.

\section{Acknowledgements}

The authors acknowledge the financial support provided by CAPES Brazilian research supporting foundation (Coordenação de Aparfeiçoamento de Pessoal de Nível Superior) and to the Applied Microbiology Specialization Course at Federal University of Parana (Universidade Federal do Paraná).

\section{References}

BASAPPA, S.C. Baker's yeast production, quality and utilization. In: JOSHI, V. K.; PANDEY, A. (Ed.). Biotechnology: food fermentation: microbiology, biochemistry, and technology. New Delhi: Educational Publishers \& Distributors, Exclusive distributors, Asiatech Publishers Inc., 1999. cap. 26, p. 1113-1143.

DEWETTINCK, K. et al. Nutritional value of bread: Influence of processing, food interaction and consumer perception. Journal of Cereal Science, v. 48, n. 2, p. 243-257, 2008. http://dx.doi. org/10.1016/j.jcs.2008.01.003

KRISTENSEN, M. B. et al. A decrease in iron status in young healthy women after long-term daily consumption of the recommended intake of fibre-rich wheat bread. European Journal of Nutrition, v. 44, p. 334-340, 2005. PMid:15349738. http://dx.doi.org/10.1007/ s00394-004-0529-4

MRVCIC, J. et al. Optimization of bioprocess for production of copper-enriched biomass of industrially important microorganism Saccharomyces cerevisiae. Journal of Bioscience and Bioengineering, v. 103, n. 4, p. 331-7, 2007. PMid:17502274. http://dx.doi.org/10.1263/jbb.103.331

PAS, M. et al. Iron enriched yeast biomass - a promising mineral feed supplement. Bioresource Technology, v. 98, n. 8, p. 1622-8, 2007. PMid:16935492. http://dx.doi.org/10.1016/j.biortech.2006.06.002

PHILPOTT, C. C.; PROTCHENKO, O. Response to iron deprivation in Saccharomyces cerevisiae. Eukaryotic Cell, v. 7, n. 1, p. 20-7, 2008. PMid:17993568. PMCid:2224162. http://dx.doi.org/10.1128/ EC.00354-07

STABNIKOVA, O. et al. Ukrainian dietary bakery products with selenium-enriched yeast. LWT, v. 41, n. 5, p. 890-895, 2008. http:// dx.doi.org/10.1016/j.lwt.2007.05.021

STEHLIK-THOMAS, V. et al. Uptake of iron by yeast cells and its impact on biomass production. Acta Alimentaria, v. 32, n. 3, p. 279287, 2003. http://dx.doi.org/10.1556/AAlim.32.2003.3.7

SUHAJDA, A. et al. Preparation of selenium yeasts I. Preparation of selenium-enriched Saccharomyces cerevisiae. Journal of Trace Elements in Medicine and Biology, v. 14, n. 1, p. 43-7, 2000. http:// dx.doi.org/10.1016/S0946-672X(00)80022-X

TAMARIT, J. et al. Colorimetric assay for the quantitation of iron in yeast. Analytical Biochemistry, v. 351, n. 1, p. 149-51, 2006. PMid:16403430. http://dx.doi.org/10.1016/j.ab.2005.12.001

WALTER, F. G. The manufacture of compressed yeast. 2. ed. London: Chapman \& Hall, 1953. 317 p.

WORLD HEALTH ORGANIZATION - WHO. Vitamin and mineral requirements in human nutrition. Geneva: WHO; Rome: FAO, 2004. Disponível em: <http://whqlibdoc.who.int/ publications/2004/9241546123.pdf>. Acesso em: 22 abr. 2008.

WINDE, J. H. D. Functional genetics of industrial yeasts. Berlin; New York: Springer, 2003. 367 p. (Topics in current genetics, n. 2).

ZIMMERMANN, M. B.; HURRELL, R. F. Nutritional iron deficiency. Lancet, v. 370, n. 9586, p. 511-20, 2007. http://dx.doi.org/10.1016/ S0140-6736(07)61235-5 


\section{Errata/Erratum}

GAENSLY, Fernanda; WILLE, Grace Maria Ferreira de Castro; BRAND, Debora e BONFIM, Tania Maria Bordin. Saccharomyces cerevisiae enriquecida com ferro mantém sua capacidade fermentativa e características de panificação. Ciênc. Tecnol. Aliment. [online]. 2011, vol.31, n.4, pp. 980-983. ISSN 0101-2061. http://dx.doi.org/10.1590/S0101-20612011000400025

Na página 980, resumo:

Onde lê-se: Saccharomy cescerevisiae

Lê-se: Saccharomyces cerevisiae 